\title{
Krill aggregation in the St. Lawrence system, and supply of krill to the whale feeding grounds in the estuary from the gulf
}

\author{
M. Sourisseau ${ }^{1, *}$, Y. Simard ${ }^{1,2}$, F. J. Saucier ${ }^{2}$ \\ ${ }^{1}$ Fisheries and Oceans Canada, Maurice Lamontagne Institute, 850 Route de la Mer, CP 1000, Mont-Joli, \\ Québec G5H 3Z4, Canada \\ ${ }^{2}$ Institut des Sciences de la Mer de Rimouski (ISMER), Université du Québec à Rimouski, 310 Allée des Ursulines, CP 3300, \\ Rimouski, Québec G5L 3A1, Canada
}

\begin{abstract}
Persistent high-density krill aggregations make the St. Lawrence Estuary and the Gulf of St. Lawrence important feeding-grounds for large marine mammals. To estimate the effects of the circulation on the seasonal krill distribution, a krill biomass-concentration equation with active vertical migration was coupled to a 3D regional sea ice-ocean circulation model. The results show recurrent spatial patterns of aggregation and advection controlled by the circulation and a high sensitivity to the parameters of the biological model. The time spent in the surface layer is crucial for the retention of organisms in the estuary. The simulated krill aggregation areas are associated with 3 processes (tidal interactions with bathymetry, wind-driven upwelling and mean circulation). Zooplankton generally aggregate near the edges of the Laurentian Channel and other secondary channels, at locations that are consistent with the sparse synoptic information on the distributions of large marine mammals in the gulf. The simulations also indicate that changes in the seasonal circulation significantly affect the krill distribution within the gulf through gyre intensities, the seasonal thermocline and the strength of the estuarine circulation. Finally, the variability of zooplankton transport to the estuary from the gulf appears to be controlled by processes acting on the circulation mode at the mouth of the estuary and estuarine pumping of the krill layer towards the head of the Laurentian Channel. The simulated krill biomass imported into the estuary changed by a factor of 2 over the 3 simulated years.
\end{abstract}

KEY WORDS: Macrozooplankton · Advection $\cdot$ Aggregation $\cdot$ Krill $\cdot$ 3D modelling $\cdot$ Hydrodynamic circulation $\cdot$ Vertical migration

\section{INTRODUCTION}

The Gulf of St. Lawrence is a semi-enclosed shelf sea covering an area of $2.3 \times 10^{5} \mathrm{~km}^{2}$. Its general estuarine circulation leads to high biological production and high biomass at all trophic levels (Dickie \& Trites 1983). In particular, some extensive krill aggregations occur in the gulf (Sameoto 1976, Simard \& Lavoie 1999), with average densities of 0.5 to $2.4 \mathrm{~g}$ dry weight $\mathrm{m}^{-3}$ and values of up to $50 \mathrm{~g}$ dry weight $\mathrm{m}^{-2}$ (Simard et al. 1986a, Simard \& Lavoie 1999). These aggregations, mainly consisting of Meganyctiphanes norvegica and Thysanoessa raschi (Simard et al. 1986a), attract populations of fishes and marine mammals (de Lafontaine et al. 1991, Kingsley \& Reeves 1998). The system is dominated by a strong seasonal cycle of the general circulation (El-Sabh 1976, Mertz et al. 1991, Saucier et al. 2003) and high interannual variability (e.g. Gilbert \& Pettigrew 1997). We can thus hypothesise that the spatial distribution of krill also follows a strong seasonal cycle that, owing to the large size of the area and the large internal variability of the water masses, has not 
yet been precisely observed and described in detail. Understanding the dynamics of the biomass distribution in conjunction with the variability of the circulation is thus essential to understanding the ecology of marine mammal populations and their management, in particular for the Saguenay-St. Lawrence Marine Park, including the region at the head of the lower St. Lawrence Estuary (Fig. 1).

The processes leading to zooplankton accumulation and retention act on several spatial and time scales (Okubo 1980, Mackas et al. 1985), and aggregations generally result from the interactions between currents, organisms' behaviour and bathymetry (Mackas et al. 1985). It is also well known that the aggregations comprise different sizes and durations ranging from several centimetres to several kilometres and from several seconds to several months, respectively. In the estuary, several processes involved in krill distribution have already been documented. One pattern, described by Simard et al. (1986a), is the aggregation of adult krill at the head of the Laurentian Channel, arising from pumping by the 2-layer estuarine circulation combined with the organisms' negative phototactism. Lavoie et al. (2000) and Cotté \& Simard (2005) have shown that tidal interactions with the bathymetry, strong upwelling and downwelling, and closed circulation cells are involved in the concentration and retention processes of this dense krill aggregation. Another pattern is the spatial separation of krill development stages between the gulf and the lower estuary as a result of different vertical swimming behaviours and depth preferenda: epipelagic larval stages are flushed downstream with the surface outflow (Runge \& Simard

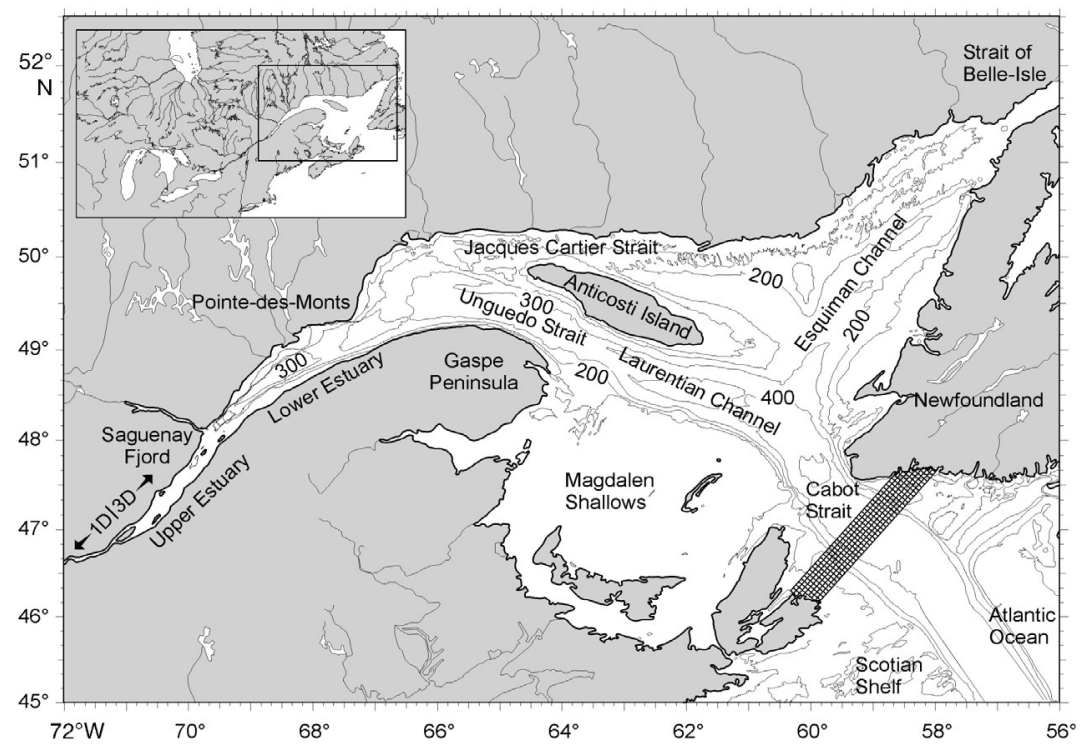

Fig. 1. Mercator depth (m) chart of St. Lawrence Estuary and Gulf of St. Lawrence. A small part of the model grid is shown along its boundary near Cabot Strait. Division between the estuary and gulf lies at Point-des-Monts
1990) and adult biomasses would return upstream in the deeper waters at the head of the Laurentian Channel in response to the 2-layer estuarine circulation. Such coupling between population dynamics and circulation has been proposed for several plankton species in other regions (Falk-Petersen \& Hopkins 1981) but has not yet been specifically examined with circulation models for the euphausiids in the St. Lawrence system. Zakardjian et al. (1999) have tested and verified this assumption for the copepod Calanus finmarchicus using a 2D idealised, (laterally averaged) estuarine model. However, the behaviour of this species is clearly different from that of euphausiids, and the marked lateral structure of the estuary (Saucier \& Chassé 2000) may strongly affect the results.

In contrast with previous studies, this paper addresses the krill aggregation dynamics over the whole St. Lawrence system, with an emphasis on the exchanges between the estuary and the gulf via the coupling of a physical circulation model with a diel vertical migration (DVM) model. We make use of a more realistic 3-D circulation model of the estuary and gulf in order to: (1) verify the above assumptions regarding the aggregation processes in the estuary, (2) estimate the distribution patterns over the whole St. Lawrence system and its variability as a function of seasonal circulation, (3) examine the factors controlling the exchanges of krill between the lower estuary and the gulf (in particular for the recruitment of krill on the whale feeding-grounds at the head of the Laurentian Channel in the Saguenay-St. Lawrence Marine Park), and (4) investigate the effects of interannual variability on the circulation.

We describe the method used to introduce the krill biomass as a primitive variable in a realistic 3D sea ice-ocean simulation validated for reproducing the tidal to seasonal circulation patterns in the estuary and gulf (Saucier et al. 2003). Krill vertical migration is added as an idealised function that represents the observed sub-daily behaviour as a function of incident light at the surface, preferred depths, and swimming speeds. We first present the basic modes of krill circulation as a function of different assumptions regarding biological parameters. The aggregation processes were found to be highly sensitive to the timing and depths of the migrations, and the basic model reproduces the high concentration areas generally observed. The strong effects of circulation variability over a range of scales in the pumping of krill into the St. Lawrence Estuary are discussed. 


\section{METHODS}

Physical model. The zooplankton transport was simulated with a 3-D hydrodynamic model of the St. Lawrence system (Saucier et al. 2003; see Fig. 1 for model domain). The model has a free surface and is coupled with a sea-ice model. The grid's horizontal resolution is $5 \mathrm{~km}^{2}$ and the vertical resolution is $5 \mathrm{~m}$ from the surface to 300 and $10 \mathrm{~m}$ in deeper layers. Owing to the time-space scales of the simulations for this large-scale system, we will not deal here with small-scale features such as krill schools and swarms. Aggregations with horizontal scales of several kilometres and durations of $1 \mathrm{~d}$ to several weeks are the focus of this work. The model computes a fully prognostic solution for currents, temperature, salinity, turbulent energy and sea-ice properties with a 5 min time-step. The atmospheric forcing is represented by nearsurface 6-hourly humidity, winds, air temperature, radiation and precipitation provided by the operational CMC/MRB Global Environmental Multiscale (GEM) model (Côté et al. 1998). The model is also driven by the tides propagating from the Atlantic Ocean, observed temperature and salinity at depth through the open boundaries, and observed daily river runoff (see Saucier et al. 2003). The physical results were compared with in situ measurements and adequately reproduced the seasonal cycle of water mass transformation and circulation. Simulations were carried out for 1997, 1998 and 1999 using different initial conditions for the physical fields based on observations made during autumn. The average currents simulated over an extended period by the model were also represented to make the description of the zooplankton transport easier to follow (Fig. 2).

Biological model. To focus on the patterns of krill advection versus vertical migrations, the effects of growth and mortality rates were ignored in the model. As a result, the simulated aggregations are 'accumulations' or 'retentions' if the biomass concentration within the aggregation either increases or remains stable, respectively (see Franks 1992). To simulate krill behaviour, a simple model of diel vertical migration, adapted from Zakardjian et al. (1999), was developed for euphausiids. The optimal depth $\left(z_{\text {opt }}\right)$ is calculated according to the time ( $t$, hours) and the organisms' average depth $(\bar{z}$, metres), migration frequency $(1 / \mathrm{N})$, and migration amplitude $(\Delta z$, metres, $)$ as

$$
z_{\text {opt }}=\bar{z}-\Delta z \times \tanh \left[\frac{4 \cos (2 \pi+t)}{N}\right]+\varepsilon
$$

Because of the relatively high swimming speed of krill (see below), a dispersion parameter, $\varepsilon$, is introduced to avoid rapid concentration of the organisms in a single layer. This parameter could be interpreted as an expression of individual variability for the optimal depth. It is a random number, estimated following a uniform distribution $(\varepsilon \in[-L / 2,+L / 2])$ at each time-step of the biological model, with $L$ (fixed at $20 \mathrm{~m}$ ) being the thickness of the optimal depth layer.

Sinking rate was ignored in the estimate of the maximal krill swimming speed because it is lower (ca. $2.2 \mathrm{~cm} \mathrm{~s}^{-1}$; Kils 1981, Cochrane et al. 1994) than sustained active swimming speeds (ca. 3 to $6 \mathrm{~cm} \mathrm{~s}^{-1}$; Hardy \& Bainbridge 1954, Tarling et al. 1999, Thomasson et al. 2003), and no energy budget is taken into account in the model. The maximal swimming speed was thus fixed at $5.5 \mathrm{~cm} \mathrm{~s}^{-1}\left(200 \mathrm{~m} \mathrm{~h}^{-1}\right)$, which corresponds to 1.5 to 3 body lengths $\mathrm{s}^{-1}$ (close to the values of about 1.5 to 4 for Meganictiphanes norvegica and Thysanoessa raschi measured in this area; Simard et al. 1986b). Such swimming speeds make the organisms independent of fine-scale turbulence, in contrast to smaller species (Yamazaki \& Squires 1996) and also to vertical currents that have maximal modelled intensities of about $1 \mathrm{~cm} \mathrm{~s}^{-1}$. The horizontal distribution of these rapid organisms will thus mainly be controlled by the horizontal current gradient (Franks 1992). The swimming activity is computed with the equation

$$
w_{z}=w_{\max } \times \tanh \left[\alpha\left(z-z_{\text {opt }}\right)\right]
$$

where $\alpha$ represents the organisms' sensitivity to removal from their optimal depth and is fixed at 0.05 . Owing to the complex social behaviour of krill aggregations recently observed (Price 1989, Greene et al. 1992, Heywood 1996, Patria \& Wiese 2004), we can also assume that the short-term velocity fluctuations around $w_{z}$ for a krill aggregation do not contribute to dispersal but rather to maintenance of the aggregation against turbulent diffusion. It is therefore difficult to assume that the nonlinearity of individual krill movements could be simulated by an additional diffusion term (Visser \& Thygesen 2003), as proposed by Wroblewski (1982) and used by Zakardjian et al. (1999) for copepods. Therefore, no biological diffusion was added to the model.

To obtain a better understanding of the horizontal aggregation processes, 3 groups of organisms with different behaviours were simulated. In the first group (Group 1), the organisms remain in the surface layer (10 to $30 \mathrm{~m}, \Delta z=0 \mathrm{~m}$ and $\bar{z}=20 \mathrm{~m}$ ) at depths corresponding to the vertical distribution of the first developmental stages of krill (eggs to furcilla; Lacroix 1961). Group 2 simulates organisms residing only in the deep layers (130 to $150 \mathrm{~m}, \Delta z=0 \mathrm{~m}$ and $\bar{z}=140 \mathrm{~m}$ ), hereafter called 'deep-dwelling krill'. In the main part of the gulf, these depths correspond to the vertical distribution of Meganictiphanes norvegica adults during the day (Sameoto 1976, Simard et al. 1986b) and to the depths of apparently non-migrating copepods (Cala- 


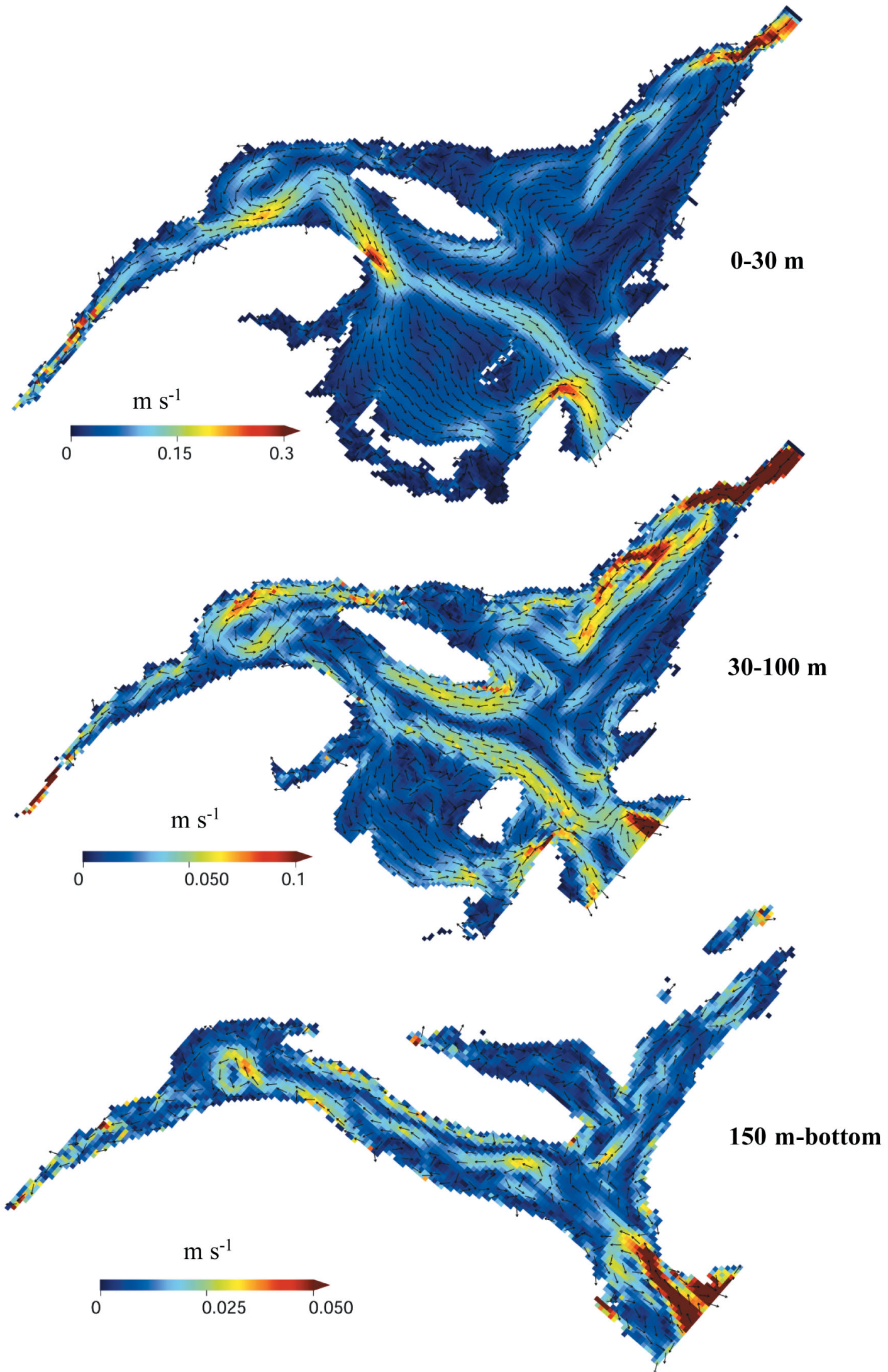

Fig. 2. Average currents simulated by model over extended period (1997 to 2003). Currents integrated over 3 layers and simulation performed with no break 
nus sp.) in the estuary. Group 3 undergoes diel vertical migrations between the depths occupied by the first 2 groups $(\Delta z=80 \mathrm{~m}$ and $\bar{z}=60 \mathrm{~m})$. The effect of the ratio of the time spent in the surface layer (where in principle the krill migrate to feed during the night) to that spent in the bottom layer during daytime was tested for values ranging from 1 to 0.4 .

Model implementation. The biological model was coupled with the physical model by introducing the following field equation for an active Eulerian tracer that is transported and diffused in the simulated 3D currents:

$$
\frac{\partial C}{\partial t}+\nabla(V C)-K_{\mathrm{h}} \nabla_{\mathrm{h}}^{2} C-\frac{\partial}{\partial z}\left(K \frac{\partial C}{\partial z}\right)=-\frac{\partial w_{z} C}{\partial z}
$$

where $C$ is the organism concentration, $V$ is the current (with 3 components, $u, v, w$ ), $K_{\mathrm{h}}$ and $K$ are the horizontal and vertical diffusion coefficients, respectively, and $w_{z}$ is the vertical swimming speed of the organisms.

The right- and left-hand sides of Eq. (3) are solved separately in the model. First, to solve the right-hand side (the evolution of the krill density field due to vertical swimming) we follow the procedure used by Andersen \& Nival (1991) and Zakardjian et al. (1999). The right-hand term is integrated using a Euler forward method with a time-step of $1 \mathrm{~min}$, therefore subcycling 5 times at each of the 5 min physical timesteps. This solution is mass conserving and avoids fast migrations compared to the thickness of the model layers (occurring mainly in the free surface layer that changes in thickness with tidal oscillation). The advection and diffusion steps (left-hand term) of the biological tracer are computed as for the other tracers (e.g. salinity, temperature and turbulent kinetic energy) using a 3D flux-corrected transport scheme (Zalesak 1979). The mass conservation was verified for the biological tracer at each time-step during the run and the precision obtained was the same as for physical tracers.

Initial conditions. The initial physical and boundary conditions were obtained from observed data interpolated on the numerical grid (Saucier et al. 2003). Several initial fields are available for the end of years 1996 to 2003 through the Atlantic Zone Monitoring Program (Therriault et al. 1998). For the biological conditions, no corresponding observations over the whole gulf are available, and the scattered data do not allow reliable interpolation. Thus in order to avoid further complexity in the simulations, we assumed a uniform initial concentration of 1 ind. $\mathrm{m}^{-3}$ between 5 and $10 \mathrm{~m}$ of depth (5 ind. $\mathrm{m}^{-2}$ ) for the 3 groups in grid cells with bottom depths greater than $25 \mathrm{~m}$. This concentration is less than those observed in the known aggregation regions (Simard et al. 1986a, Lavoie et al. 2000), but the total cumulated biomass of about $10^{5}$ tons prescribed this way in the model (with a mean wet weight of $0.2 \mathrm{~g}$ ind. ${ }^{-1}$; Simard \& Lavoie 1999) is on the order of magnitude of the estimated $4 \times 10^{5}$ to $10^{6} \mathrm{t}$ found in the estuary and gulf (Runge \& Joly 1995). At the boundaries, no organisms were introduced, assuming that the import of euphausiids is negligible, an assumption in agreement with several studies considering the Gulf of St. Lawrence as an exporter of organisms that can greatly influence euphausiid populations as far as the Scotian Shelf and Georges Bank (Herman et al. 1991).

\section{RESULTS}

\section{Aggregation area}

For the 3 simulated years (1997, 1998 and 1999) and in the first simulation (Group 1), whereby the krill is forced to remain in the surface layer, the organisms
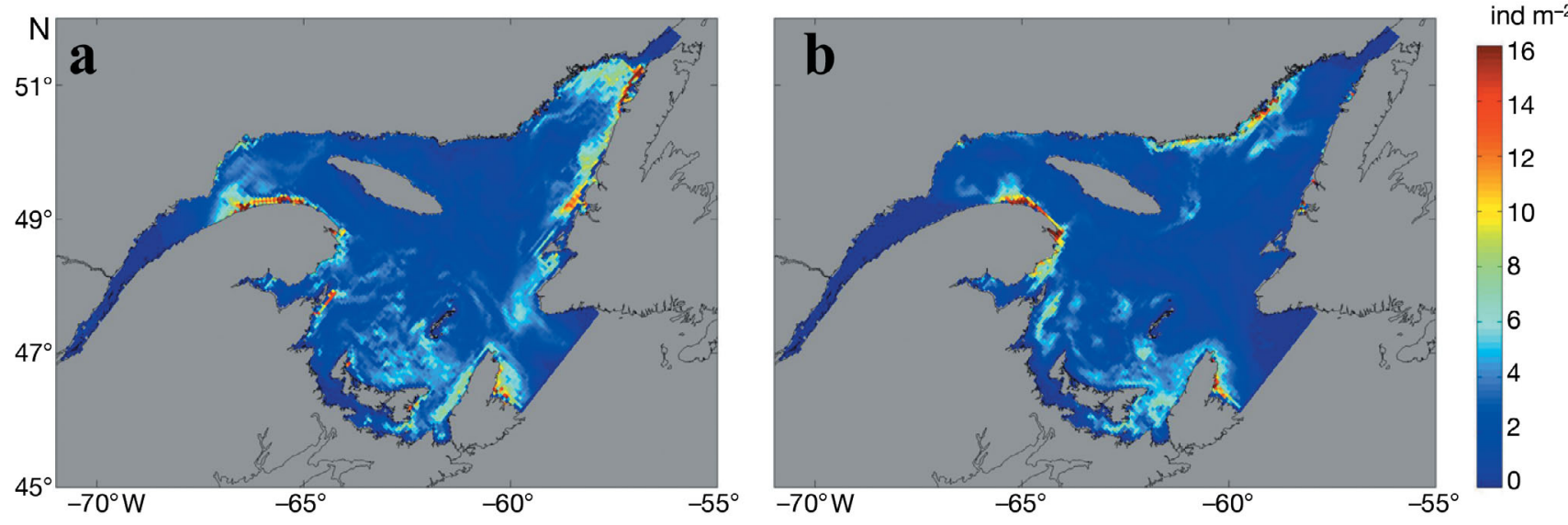

Fig. 3. Meganictiphanes norvegica and Thysanoessa raschi. Monthly averaged concentration of upper water-column krill group in (a) February and (b) April 1997. Simulation was started on 8 December 1996 with uniform distribution of 1 ind. $\mathrm{m}^{-2}$ integrated throughout the water column 
were largely flushed out of the estuary after only 1 to 2 mo (Fig. 3a). This was expected, given the general estuarine circulation of the system. However, at the mouth of the estuary, the lateral circulation modes also become important. In the NW gulf, the nearly permanent large-scale cyclonic Anticosti Gyre (El-Sabh 1976) and the Gaspé Current are the 2 main features of horizontal circulation (Fig. 2). The Gaspé Current is initiated with freshwater outflow from the estuary, runs along the south shore, and efficiently displaces a volume flux 100 times higher than the St. Lawrence runoff toward the southern gulf (El-Sabh 1976, Tang 1980a, Benoit et al. 1985, Mertz et al. 1988). Thus, the organisms exit mainly via the Gaspé Current. However, the Gaspé Current also often leaves the coast to partly recirculate through the gyre, and thus some organisms can remain trapped in the northwestern gulf for up to 6 mo (Fig. 3b). A coastal aggregation near the end of the Gaspé Peninsula was formed during the winter in the frontal area between the Gaspé Current and a cyclonic circulation that was briefly simulated in 1997 in the northwestern gulf. After a slowdown of the cyclonic gyre in January and the setup of a stable anticyclonic circulation in the following month, this aggregation then moved downstream along the coast before dis- persing on the Magdalen Shallows following the general cyclonic circulation of the gulf. Significant export was observed through Cabot Strait: for each simulated year, $40 \%$ of the initial total biomass was exported during the first 3 mo and $80 \%$ during the whole year. A large part of the krill larvae that remain in the surface layers for 2 or 3 mo are thus flushed out of the gulf. In the NE gulf (near the Strait of Belle-Isle), exchanges of organisms between the north shore of the gulf and the west coast of Newfoundland can be intense under favourable wind conditions.

In the second simulation (Group 2), whereby the organisms remain in the deep layer, the aggregations appear closely linked with bathymetry. Under the effect of the tidal currents oriented towards sloping bathymetry (see Cotté \& Simard 2005), these deepdwelling zooplankton are aggregated on most slopes at the margin of the basin. This process is the dominant accumulation mechanism, occurring on short time scales and generating aggregations after only $1 \mathrm{wk}$ simulation (Fig. 4a). On longer time scales, the residual circulation produces several major and year-round persistent aggregation areas (Fig. 4b-d): the head of the Laurentian Channel, the Jacques-Cartier Strait, the Anticosti Gyre, and the north shore near the Strait
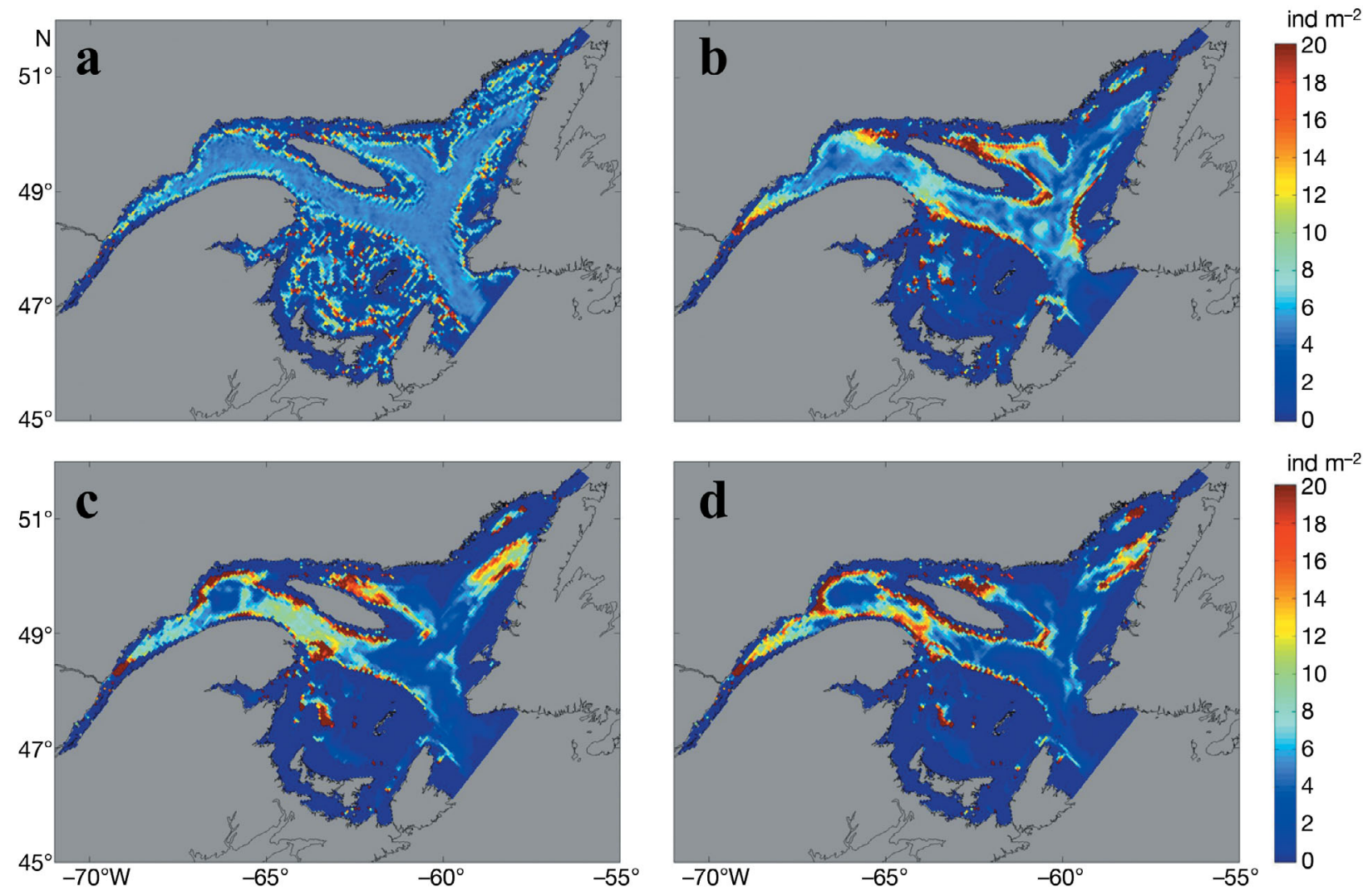

Fig. 4. Meganictiphanes norvegica and Thysanoessa raschi. (a) Deep-dwelling krill group concentration on 12 December 1997 and averaged concentrations from (b) January to February, (c) May to June, and (d) July to August. Initial conditions as in Fig. 3 
of Belle-Isle. Significant variations in the intensity of the aggregation and retention processes are simulated as results of seasonal circulation changes. For instance, the aggregations west and east of the Jacques-Cartier Strait result from 2 mechanisms. The western aggregation was built up during the first 2 mo of the winter of 1997 (Fig. 4b) through an episodic anticyclonic circulation cell in the northwestern gulf. The aggregation then dispersed and was advected westward during the following 2 mo (Fig. 4c), when the cyclonic circulation resumed. On the eastern side of the strait, the organisms were pushed westward along the slope of the north Anticosti Channel by the inflow of dense Labrador waters entering through the Strait of BelleIsle. Owing to the deep distribution of the organisms relative to the strait's depth and deep-water blocking from sill hydrodynamics, as described for the head of the Laurentian Channel (see Lavoie et al. 2000), an accumulation was created at the head of the north Anticosti Channel. In the absence of diel vertical migration of the zooplankton, the aggregation was then transported SE along the north shore of Anticosti Island (Fig. 4b). After reaching the Laurentian Channel, the organisms were transported to the NW along the south coast of Anticosti Island via the deep flow of the 2-layer estuarine circulation (Fig. 4c). Significant exchanges of organisms occur between the 2 sides of the Laurentian Channel through mesoscale advection and deep eddies (Fig. 4c,d).

The simulations also highlight the importance of the Anticosti Gyre on the zooplankton dynamics of the estuary. Under the effects of both the 2-layer estuarine circulation of Atlantic and Labrador waters towards the head of the Laurentian Channel and wind driven upwelling events along the north shore (Mertz et al. 1991), deep-dwelling organisms are accumulated on the north shore. They are then trapped inside the cyclonic gyre in the northwestern gulf. This area represents the main source of the organisms later found in the St. Lawrence Estuary.

The last persistent aggregation of deep-dwelling krill is located in the NE gulf and is linked to local bathymetry. The krill are concentrated at the head of the Esquiman Channel and in a mesoscale basin (Mecatina), from which they cannot escape without moving over the edges. Other simulated accumulations are linked to wind-driven upwelling events. For example, on the west coast of Newfoundland, NE winds produce upwelling events that generate an aggregation on the slope (Fig. 4b). However, these aggregations are
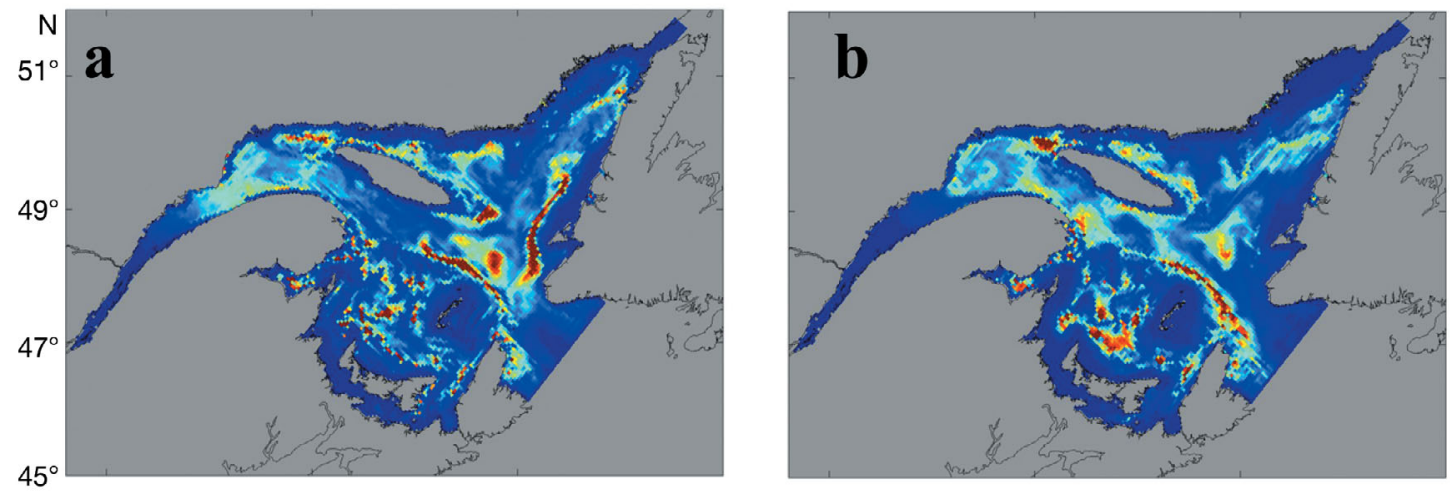

ind $\mathrm{m}^{-2}$
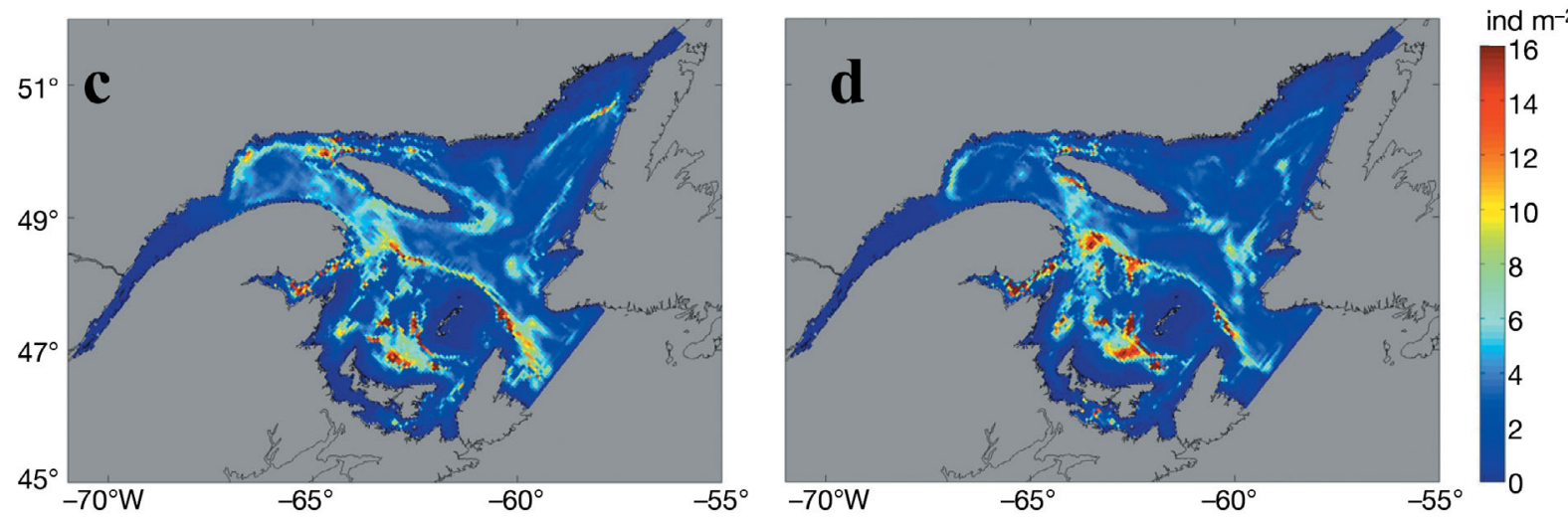

Fig. 5. Meganictiphanes norvegica and Thysanoessa raschi. Monthly averaged concentration of vertically migrating krill group (12 h depth:12 h surface) in (a) February and (b) April 1997, and averaged concentration during periods from (c) May to June and (d) July to August. Initial conditions as in Fig. 3 
shorter-lived than those described above and their maximal simulated concentration is lower.

As expected, the transport of organisms undergoing diel vertical migration (Group 3) is highly dependent on the time they spend in the upper water column. Their simulated aggregations are thus less dense and less persistent than those of organisms remaining in the deep layer (Fig. 5). However, they are also aggregated on slopes, in particular around Jacques-Cartier Strait, along the Laurentian Channel, and on the west coast of Newfoundland. Depending on the time spent in the surface layers during the night, some organisms also invaded the Magdalen Shallows and the south coast of the Gaspé Peninsula. An equal time spent in the surface layer and in the deep layer results in rapid advection of the organisms. Their residence time in the estuary is around $3 \mathrm{mo}$, which is close to the value observed for the organisms staying in the surface layer (Figs. 3a \& 5a). The residence time in the lower estuary and in the gulf varies only slightly for organisms staying 6,10 , or $12 \mathrm{~h}$ in the surface layers (results not shown). From the integrated mean current profile at the Pointe-des-Monts section (results not shown), the ratio between the time spent in the deep layer relative to that spent in the surface layer (above $50 \mathrm{~m}$ ) must be around 6:1 to maintain the organisms in the same area, a value close to the estimate of Zakardjian et al. (1999) using a 2D model of the estuary. The simulated vertically migrating organisms are thus advected outside the estuary and no persistent aggregation is formed at the head of the Laurentian Channel (Fig. 5c). Furthermore, the loss through the open boundary at Cabot Strait is also high, reaching $60 \%$ of the initial biomass over 1 yr. Very low abundance is maintained in the NW during the summer (Fig. 5d), while the Magdalen Shallows contain dense aggregations moving through on their way to exit the gulf.

\section{Krill exchange between the lower estuary and the gulf}

The residual water fluxes (Fig. 6) in the Pointe-des-Monts section (see Fig. 1) computed for 1997 highlight the seasonality in the deep layer circulation, in agreement with other recent results (e.g. Smith et al. 2006a,b). The flux in the surface layers (between 0 to $40 \mathrm{~m}$ ) is obviously downstream (close to 0.2 Sverdrup, Sv), but, as indicated previously, the direction and the intensity of the simulated fluxes in the other two layers (40 to $100 \mathrm{~m}$ and below $100 \mathrm{~m}$ ) are subject to seasonal variations. The fluxes have an upstream direction in the intermediate layer (between 40 and $100 \mathrm{~m}$ ), but the mean is near zero over a period of about a 4 mo during autumn and winter. During this period the surface layer deepens to approximately 100 to $120 \mathrm{~m}$ in depth in the Gulf of St. Lawrence and gradually encompasses, and thus renews, the previous year's summer cold intermediate layer (CIL). Heat removal, sea-ice formation and strong wind-stress produce high vertical diffusion of scalars and momentum through this new layer, which is in contact with the deep Atlantic waters of the Laurentian Channel. The circulation is then 2-layered, with the thick winter surface layer generally moving out of the estuary and the deep Atlantic waters circulating more intensely through the Laurentian Channel. In the present simulation, the circulation in the deep layer is highly variable, with a mean upstream flow of about $-0.1 \mathrm{~Sv}$. Several strong inflow events are also visible during autumn and winter $(-0.4 \mathrm{~Sv})$ in association with high outflow events in the winter-surface layer. In early spring, freshwater runoff, sea-ice melt, and vernal warming produce a new stable surface layer over the estuary and gulf that prevents frictional stress from entraining the circulation below. Near $100 \mathrm{~m}$ depth, the circulation reverses and new CIL waters move fairly swiftly into the estuary (see Smith et al. 2006b). During spring and summer, a

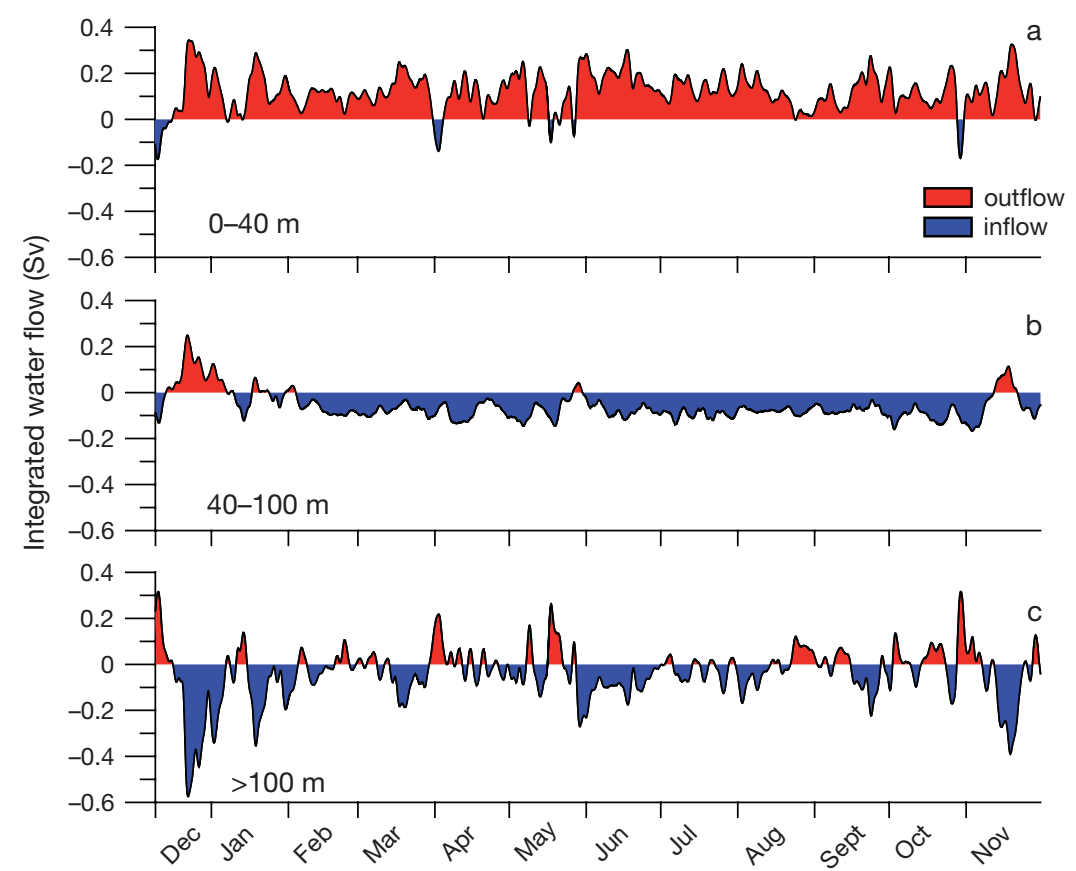

Fig. 6. Vertically and horizontally integrated residual water-flux series through Pointe-des-Monts section between estuary and Gulf of St. Lawrence for 1997. Positive values (red) indicate outflow. Tidal components filtered using Godin filters 


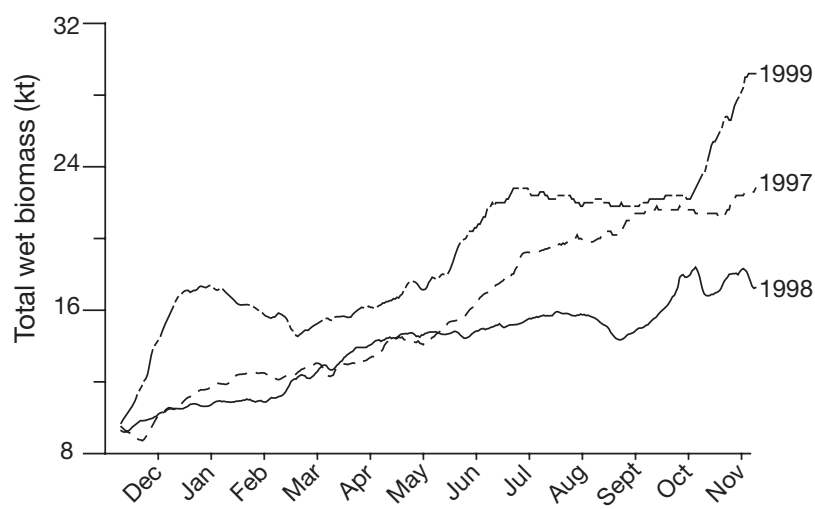

Fig. 7. Meganictiphanes norvegica and Thysanoessa raschi. Annual series of integrated simulated biomass of deepdwelling krill group in St. Lawrence Estuary for 1997 to 1999. Simulations were started with same initial conditions on 8 December for all years

regular upstream flow in the intermediate layer was simulated (around $-0.1 \mathrm{~Sv}$ ).

In agreement with the simulated water flux in the deep layers, the total biomass of deep-dwelling krill in the lower estuary steadily increases over the year for all years (Fig. 7). The initial total biomass of $8 \mathrm{kt}$ reaches values between 16 and $30 \mathrm{kt}$ after $1 \mathrm{yr}$, with the estuarine pumping effect leading to a 2 - to 4 -fold increase from the initial biomass. This represents around $30 \%$ of the total biomass left in the domain after 1 yr. A 2-fold interannual variability is also simulated, with the pumping of the organisms towards the head of the Laurentian Channel being most effective in 1999. In contrast to water fluxes, no interannual recurrent increases in the import cycle related to the seasonal fluctuation in freshwater input and vertical stratification appear in the simulated accumulation series. Other periods (December, June and November 1999; Fig. 7) are characterised by a higher inflow of organisms.

The absence of a seasonal pattern in the 1997 simulated biomass accumulation of deep-dwelling krill in the Lower Estuary is due to the combination of the $\mathrm{N}$ to $\mathrm{S}$ variations in the flow pattern at the mouth of the estuary and the concentration of organisms in the imported waters. This concentration was higher in waters originating from the north shore than in those from the south shore because the zooplankton were previously aggregated along the north shore of the NW gulf via the tidal interactions with the slopes, the gyre activity, and some wind-driven upwelling events (e.g. Lacroix 1987) (present Fig. 4). Parts of this aggregation were forced and drawn into the estuary in response to its cyclonic circulation pattern whereas currents along the north shore were directed upstream. The average, simulated, upstream currents in all layers were thus mainly located on the north side of the estuary, in agreement with the cyclonic circulation observed in the estuary (Koutitonsky 1979, Tang 1980a) and smaller domain simulations (Saucier \& Chassé 2000). However, the $\mathrm{N}$ to $\mathrm{S}$ variability in the local circulation at the mouth of the Lower Estuary was associated with frequent synoptic scale reversals in the deep, intermediate and surface layers (Fig. 8). Such a flow inversion in deep layers (such as the anticyclonic circulation at the end of May 1997) was responsible for the poor recruitment of deep-dwelling zooplankton into the estuary and resulted in the absence of a seasonal modulation of krill pumping into the estuary. The intense krill pumping events in the estuary in 1999 resulted from favourable concentrations of krill on the north side of the mouth combined with a corresponding northern inflow. All factors acting on the circulation mode at the mouth of the Lower Estuary and on the availability of a source krill-aggregation along the north shore thus have a strong influence on the recruitment of deep-dwelling zooplankton into the estuary.

\section{DISCUSSION}

\section{General patterns}

In accordance with Franks (1992), the high swimming speeds of organisms allow them to be independent of the simulated vertical currents, and their hori-

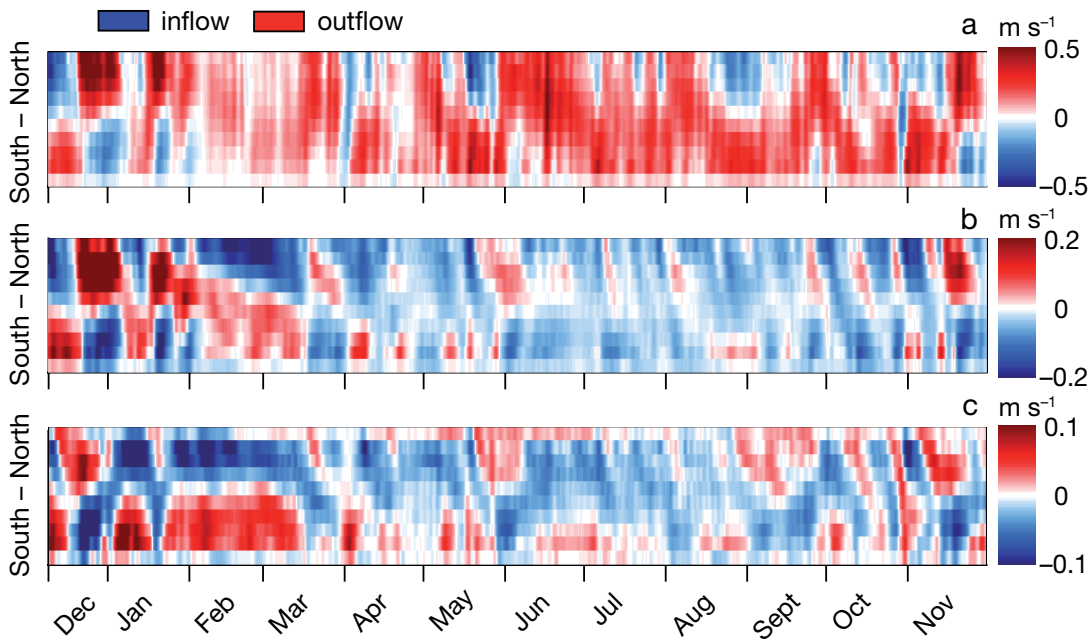

Fig. 8. Cross-channel series of along-channel residual currents for 1997 at Pointe-des-Monts section located between estuary and Gulf of St. Lawrence for (a) surface, (b) $60 \mathrm{~m}$, and (c) $130 \mathrm{~m}$. Positive values (red) indicate outflow. Tidal components filtered using Godin filters 
zontal aggregation is thus controlled by the horizontal current gradient. As observed in submarine canyons (Greene et al. 1988, Allen et al. 2001) and at the head of the estuary (Lavoie et al. 2000), migrating macrozooplankton with high swimming capacities are concentrated on steep bottom slopes throughout the Gulf of St. Lawrence, primarily due to tidal oscillations (Cotté $\&$ Simard 2005). Our results thus extend the dynamics already described for the estuary to the entire gulf, in agreement with studies describing abrupt sloping bottoms as areas of major trophic exchanges in response to local biomass aggregation, notably for vertically migrating organisms (see review by Genin 2004).

The model provided evidence that the organisms accumulate in key areas determined by the regional circulation (Jacques-Cartier Strait, around Anticosti Island, and along the north shore in the NW part of the gulf). These new aggregation areas outside the estuary revealed by the simulations appear to be stable over long time scales even though their concentrations are lower than that at the head of the Laurentian Channel. As krill is an essential food source for large marine mammals, the good match between the overall distribution of baleen whales reported in the survey available for the gulf (Kingsley \& Reeves 1998) and the average distribution of the simulated krill (Fig. 9) is not surprising. We chose to use the distribution of the 3 largest whale species found in the St. Lawrence Estuary and Gulf on the basis of their diet or their trophic position. The diet of the blue whale Balaenoptera musculus is thought to be essentially made up of krill (Schoenherr

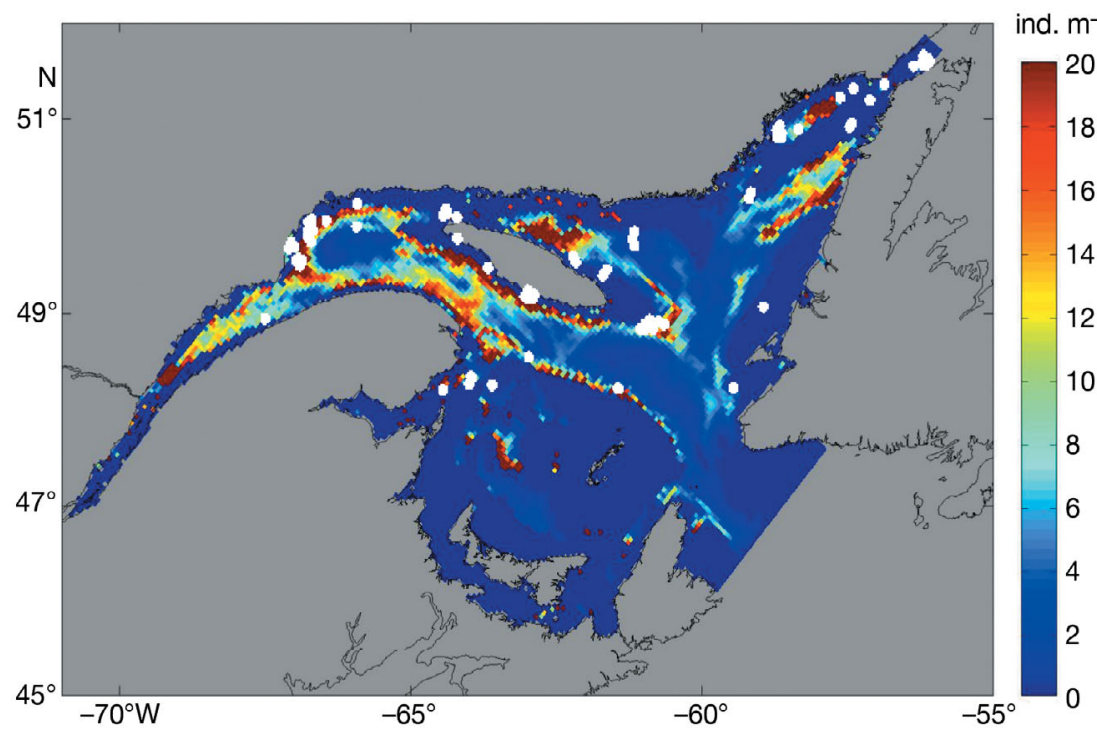

Fig. 9. Comparison between summer distribution of large whale species in the Gulf (solid white circles) from the only systematic survey made (1995 and 1996 aerial survey by Kingsley \& Reeves 1998) and averaged simulated abundance of zooplankton during July and August 1997. Whale species comprise blue, fin, and humpback (see Kingsley \& Reeves 1998 for more details)
1991, Fiedler et al. 1998), and the trophic levels of the finback and humpback whales Balaenoptera physalus and Megaptera novaeangliae in the St. Lawrence system are very low (Borobia et al. 1995), indicating a high contribution of zooplankton such as krill in their diet. The good match between krill aggregations and the period when whales move into the gulf to restore their lipid reserves (Borobia et al. 1995) supports the accuracy of the krill aggregation dynamics simulated by the model. Moreover, the existence of such aggregations is largely confirmed by acoustic surveys in the gulf (Sameoto 1976, Simard unpubl. data). Such prey/ predator mesoscale co-distributions have been observed in the St. Lawrence Estuary (Simard \& Lavoie 1999) and other blue whale feeding areas (Croll et al. 1998, 2005, Fiedler et al. 1998), indicating that krill accumulation dynamics is the key factor. Moreover, since the whale observations are from different years (1995 and 1996) than the simulation results (1997), this indicates a certain degree of stability in the aggregation processes and spatial distribution between years, as shown by the simulations for the $3 \mathrm{yr}$.

Krill population dynamics were not included in this study because this would have required several additions to the model and the data were insufficient for proper implementation and validation. Nevertheless, the $3 \mathrm{yr}$ of simulated results showed that estuarine krill pumping intensity and the circulation mode at the mouth of the estuary can generate fluctuations of a factor of 2 for the total krill biomass in the Lower Estuary. Over shorter time and space scales, larger fluctuations would be expected, such as those observed by Simard \& Lavoie (1999) near the head of the Laurentian Channel.

\section{Sensitivity to biological parameters}

The differences between the simulated distribution patterns for the deepdwelling and the vertically migrating organisms clearly show the sensitivity of the results to the vertical migration model. This involves the residence time and mean depth in the surface layer (below or above the thermocline) and the seasonal cycle of vertical migration. Thysanoessa raschi and Meganictiphanes norvegica are able to adapt their vertical distribution patterns according to their physiological condition and to environmental factors such as temperature, food concentration, in situ light levels or predators (Zelikman et al. 1978, 1979, Fischer \& Visbeck 
1993, Buchholz et al. 1995, Bergström \& Strömberg 1997, Onsrud \& Kaartvedt 1998, Pearre 2003, Tarling 2003). Although krill cross the thermocline (Simard et al. 1986b), their particular location in relation to this boundary (and particularly the exact duration of their stay above it, where mean currents are stronger and outflowing) are not well known and have not been considered in any model. Fine-scale, nocturnal, vertical migration appears to be a key factor that interacts with several tidal and seasonal processes and strongly affects aggregation/dispersion patterns, and could explain the lack of retention of vertically migrating organisms in the estuary. A synergy for retention could also exist in the vicinity of the upwelling areas, where new primary production should occur. Krill would first be aggregated in deep layers during the day against the shelf slope and, by spending less time feeding in these productive and concentrated food areas, subsequently be less exposed to surface currents during the night. Such processes could explain the significant positive correlation reported by Sameoto (1976) between euphausiid abundance and chlorophyll a concentrations in the gulf.

The in situ light level (Simard et al. 1986b, Tarling et al. 1999), which is affected by day lenght, phytoplankton (Kaartvedt et al. 1996), river input of terrigenous material and sea-ice cover, is another source of seasonal control that was ignored. Sea-ice covers more than $50 \%$ of the gulf surface during several months (e.g. Saucier et al. 2003, Pellerin et al. 2004). A simple light-level model controlling the mean depth of krill would concentrate the organisms in the upper layers during the 3 winter months, and $50 \%$ of the krill would thus be lost from the estuary and gulf during the winter months without any return during spring. This stresses the importance of investigating the existence of an endogenous, seasonal, vertical migration rhythm in this system. In addition, the physical processes reducing sea-ice formation (tidal and wind driven upwellings and the 2-layer estuarine circulation; Saucier et al. 2003) are also largely responsible for krill aggregation. Interannual variability in sea-ice cover (and hence in light penetration) could affect krill aggregation through a higher export in years with denser sea-ice cover. Taking into account light level effects requires numerous biological assumptions and validation data. Since these data are lacking, the biological model must remain simple. However, we did explore the effect of day length on the distribution dynamics. Residence times of 10 and 6 $\mathrm{h}$ in the surface layer ( 0 to $30 \mathrm{~m}$ ), corresponding to the length of the spring and summer daylight periods, slightly changed the aggregation patterns (results not shown), but also resulted in a lack of retention in the estuary in contrast with all field observations, which again stresses the critical importance of nocturnal vertical distribution. The deep-dwelling organisms are adequately represented by overwintering macrozooplankton such as large calanoid copepods, which have well-known overwintering periods at depth in high latitudes, and also by krill remaining in deep layers during the sea-ice period, or vertically migrating with very short individual residence times above the thermocline, as suggested by Simard et al. (1986b). This assumption of krill behaviour appears to be necessary to validate the 'estuarine pumping system' as an effective mechanism for accumulating and maintaining the krill population at the head of the Laurentian Channel.

\section{Sensitivity to physical model}

The low spatial resolution of the model relative to the size of the estuary resulted in insufficient mixing at the head of the Laurentian Channel and difficulties in balancing the salt and temperature budget in the estuary. This problem was solved by increasing the horizontal eddy viscosity and diffusivity coefficients $\left(K_{\mathrm{h}}\right)$ in the estuary. The simulated surface salinity and temperature thus fit better with the weekly observations in the surface layer. This correction generates fast exchanges from the north to the south side of the estuary, especially in the surface layers where currents are highest. It also blunts the upstream flow close to the north shore of the estuary, which is well defined in a higher resolution model of the estuary by Saucier \& Chassé (2000). A higher resolution model now needs to be implemented to test the importance of small-scale processes in the residence time of organisms in the estuary. Sensitivity tests of the crosschannel gradient current and of the deep-water inflow period to the horizontal eddy viscosity and diffusivity coefficients $\left(K_{\mathrm{h}}\right)$ were conducted by applying the gulf values over the entire model domain. The current intensity at the mouth of the estuary obviously increased, but the rate of changes in the circulation modes and the laterally integrated water inflow in the estuary remained stable.

\section{Krill and deep-dwelling macrozooplankton exchanges between estuary and gulf}

The simulated dynamics near the mouth of the estuary highlight the high variability of the current system over a wide range of time scales. The spatial extent and the persistence of the small anticyclonic gyre observed by Tang (1980a) below the surface waters near the mouth of the estuary in September appear 
small. The N-S cross-channel current described by Tang (1980a) in the surface waters could result from a short period of outflow along the north shore in the Pointe-des-Monts section. Our simulations and previous observations of gulf inflow in the surface waters indicate that this circulation mode seems temporary (Koutitonsky 1979, Gratton et al. 1988). All factors acting on the pumping of water towards the head of the Laurentian Channel and the circulation mode at the mouth of the estuary influence krill exchanges between the estuary and the gulf and generate variability in total krill biomass within the estuary. The stability of the Gaspé Current (Mertz \& El-Sabh 1988), the wind conditions on the north shore off the Pointe-desMonts section (Lacroix 1987), the intensity of the freshwater discharge (Tang 1980b, Koutitonsky \& Bugden 1991), neap and spring tides, and the intensity of the Anticosti Gyre are thus the most important factors involved in regulating zooplankton exchange. Dense concentrations pumped towards the head of the Laurentian Channel should then persist there under the combined action of additional tidal concentration processes and recirculation (Lavoie et al. 2000, Cotté \& Simard 2005).

Overall, trends emerge for deep-dwelling organisms inhabiting the CIL, deep-dwelling organisms staying below the $\mathrm{CIL}$, and organisms vertically migrating between one of these layers and the surface layer. For the deep-dwelling groups, the pumping towards the head of the Laurentian Channel and the circulation mode at the mouth control the efficiency of zooplankton accumulation in the estuary. The accumulation of the group confined in the CIL should be more stable, since the water flow within the CIL is upstream most of the time (Fig. 6b) and is less variable than in the deeper Atlantic waters. The accumulation of organisms remaining below the CIL should be highest from the end of the summer to the beginning of the spring, before stratification is established. During the rest of the year, the strong cyclonic circulation into the estuary could generate a krill import in the estuary and at the head of the Laurentian Channel. Finally, for migrating organisms that do not avoid the fast-moving surface layers, the 'estuarine pumping system' is not able to explain an aggregation at the head of the Laurentian Channel. The existence of a strong cyclonic circulation in the estuary and small-scale processes related to the bathymetry, tides and winds appear to be the most important factors explaining the import of vertically migrating organisms.

Acknowledgements. This work was funded by Fisheries and Oceans Canada. We thank F. Roy and S. Senneville for their assistance in the model development.

\section{LITERATURE CITED}

Allen SE, Vindeirinho C, Thomson RE, Foreman MGG, Mackas DL (2001) Physical and biological processes over a submarine canyon during an upwelling event. Can J Fish Aquat Sci 58:671-684

Andersen V, Nival P (1991) A model of the diel vertical migration of zooplankton based on euphausiids. J Mar Res 49: 153-175

Benoit J, El-Sabh MI, Tang CL (1985) Structure and seasonal characteristics of the Gaspé Current. J Geophys Res C 90: 3225-3236

Bergström B, Strömberg JO (1997) Behavioural differences in relation to pycnoclines during vertical migration of the euphausiids Meganyctiphanes norvegica (M. Sars) and Thysanoessa raschi (M. Sars). J Plankton Res 19:255-261

Borobia M, Gearing PJ, Simard Y, Gearing JN, Béland P (1995) Blubber fatty acids of finback and humpback whales from the Gulf of St. Lawrence. Mar Biol 122: 341-353

Buchholz F, Buchholz C, Reppin J, Fischer J (1995) Diel vertical migrations of Meganyctiphanes norvegica in the kattegat: Comparison of net catches and measurements with acoustic doppler current profilers. Helgol Meeresunters 49:849-866

Cochrane NA, Sameoto DD, Belliveau DJ (1994) Temporal variability of euphausiid concentrations in a Nova Scotia shelf basin using a bottom-mounted acoustic doppler current profiler. Mar Ecol Prog Ser 107:55-66

Côté J, Desmarais JG, Gravel S, Méthot A, Patoine A, Roch M, Staniforth A (1998) The operational CMC-MRB global environmental multiscale (GEM) model: Part II - results. Mon Weath Rev, Met Serv Can 126:1397-1418

Cotté C, Simard Y (2005) The formation of rich krill patches under tidal forcing at whale feeding ground hot spots in the St. Lawrence Estuary. Mar Ecol Prog Ser 288:199-210

Croll DA, Tershy BR, Hewitt RP, Demer DA and 8 others (1998) An integrated approach to the foraging ecology of marine birds and mammals. Deep-Sea Res II 45:1353-1371

Croll DA, Marinovic B, Benson S, Chavez FP, Black N, Ternullo R, Tershy BR (2005) From wind to whales: trophic links in a coastal upwelling system. Mar Ecol Prog Ser 289: $117-130$

de Lafontaine Y, Demers S, Runge J (1991) Pelagic food web interactions and productivity in the Gulf of St. Lawrence: a perspective. Can Spec Publ Fish Aquat Sci 113:99-123

Dickie LM, Trites RW (1983) The Gulf of St. Lawrence. Ecosyst World 26:403-425

El-Sabh MI (1976) Surface circulation pattern in the Gulf of St. Lawrence. J Fish Res Board Can 33:124-138

Falk-Petersen S, Hopkins CCE (1981) Ecological investigations on the zooplankton community of Balsfjorden, northern Norway: population dynamics of the euphausiids Thysanoessa inermis (Kroyer), Thysanoessa raschi (M. Sars) and Meganyctiphanes norvegica (M. Sars) in 1976 and 1977. J Plankton Res 3:177-192

Fiedler PC, Reilly SB, Hewitt RP, Demer DA and 6 others (1998) Blue whale habitat and prey in the California Channel Islands. Deep-Sea Res II 45:1781-1801

Fischer J, Visbeck M (1993) Seasonal variation of the daily zooplankton migration in the Greenland Sea. Deep-Sea Res I 40:1547-1557

Franks PJS (1992) Sink or swim: accumulation of biomass at fronts. Mar Ecol Prog Ser 82:1-12

Genin A (2004) Bio-physical coupling in the formation of zooplankton and fish aggregations over abrupt topographies. J Mar Syst 50:3-20 
Gilbert D, Pettigrew B (1997) Interannual variability (1948-1994) of the CIL core temperature in the Gulf of St. Lawrence. Can J Fish Aquat Sci 54:57-67

Gratton Y, Mertz G, Gagné JA (1988) Satellite observations of a tidal upwelling and mixing in the St. Lawrence estuary. J Geophys Res C 93:6947-6954

Greene CH, Wiebe PH, Burczynski J, Youngbluth MJ (1988) Acoustical detection of high-density krill demersal layers in the submarine canyons off Georges Bank. Science 241: 359-360

Greene CH, Widder E, Youngbluth MJ, Tamse A, Johnson GE (1992) The migration behavior, fine structure, and bioluminescent activity of krill sound-scattering layers. Limnol Oceanogr 37:650-658

Hardy AC, Bainbridge R (1954) Experimental observations on the vertical migrations of plankton animals. J Mar Biol Assoc UK 33:409-448

Herman AW, Sameoto DD, Chen S, Mitchell MR, Petrie B, Cochrane N (1991) Sources of zooplankton on the Nova Scotia shelf and their aggregations within deep-shelf basins. Cont Shelf Res 11:211-238

Heywood KJ (1996) Diel vertical migration of zooplankton in the Northeast Atlantic. J Plankton Res 18:163-184

Kaartvedt S, Melle W, Knutsen T, Skjoldal HR (1996) Vertical distribution of fish and krill beneath water of varying optical properties. Mar Ecol Prog Ser 136:51-58

Kils U (1981) Size dissociation in krill swarms. Kiel Meeresforsch 5:262-263

Kingsley MCS, Reeves RR (1998) Aerial surveys of cetaceans in the Gulf of St. Lawrence in 1995 and 1996. Can J Zool 76:1529-1550

Koutitonsky VG (1979) Transport de masses d'eau à l'embouchure de l'estuaire du Saint-Laurent. Nat Can 106:75-88

Koutitonsky VG, Bugden GL (1991) The physical oceanography of the Gulf of St. Lawrence: a review with emphasis on the synoptic variability of the motion. Can Spec Publ Fish Aquat Sci 113:57-90

Lacroix G (1961) Les migrations verticales des euphausides à l'entrée de la baie des Chaleurs. Nat Can 88:257-316

Lacroix J (1987) Etude descriptive de la variabilité spatio-temporelle des phénomènes de surface de l'estuaire maritime et de la partie ouest du Golfe du Saint-Laurent à l'aide d'images thermiques du satellite NOAA-7 MSc dissertation, Université du Québec à Rimouski, Rimouski, Canada

Lavoie D, Simard Y, Saucier FJ (2000) Aggregation and dispersion of krill at channel heads and shelf edges: the dynamics in the Saguenay-St. Lawrence Marine Park. Can J Fish Aquat Sci 57:1853-1869

Mackas DL, Denman KL, Abbott MR (1985) Plankton patchiness: biology in the physical vernacular. Bull Mar Sci 37 : 652-674

Mertz G, El-Sabh MI (1988) An autumn instability event in the Gaspé Current. J Phys Oceanogr 19:148-156

Mertz G, El-Sabh MI, Proulx D, Condal AR (1988) Instability of a buoyancy-driven coastal jet: the Gaspé Current and its St. Lawrence precursor. J Geophys Res C 93:6885-6893

Mertz G, Koutitonsky VG, Gratton Y (1991) On the seasonal cycle of the Gaspé Current. Can Spec Publ Fish Aquat Sci 113:149-152

Okubo A (1980) Diffusion and ecological problems: mathematical models. Biomathematics 10:1-250

Onsrud MSR, Kaartvedt S (1998) Diel vertical migration of the krill Meganyctiphanes norvegica in relation to physical environment, food and predators. Mar Ecol Prog Ser 171: 209-219

Patria MP, Wiese K (2004) Swimming in formation in krill (Euphausiacea), a hypothesis: dynamics of the flow field, properties of antennular sensor systems and a sensorymotor link. J Plankton Res 26:1315-1325

Pearre SJ (2003) Eat and run? The hunger/satiation hypothesis in vertical migration: history, evidence and consequences. Biol Rev 78:1-79

Pellerin P, Ritchie H, Saucier FJ, Roy F, Desjardins S, Valin M, Lee V (2004) Impact of a two-way coupling between an atmospheric and an ocean-ice model over the Gulf of St. Lawrence. Mon Weath Rev Met Serv Can 132:1379-1398

Price HJ (1989) Swimming behavior of krill in response to algal patches: a mesocosm study. Limnol Oceanogr 34: 649-659

Runge J, Joly P (1995) Zooplankton (euphausiids and Calanus) in the Estuary and Gulf of St. Lawrence. Can Manuscr Rep Fish Aquat Sci 2323:123-132

Runge JA, Simard Y (1990) Zooplankton of the St. Lawrence Estuary: the imprint of physical processes on its composition and distribution. In: El-Sabh MI, Silverberg N (eds) Oceanography of a large-scale estuarine system: the St. Lawrence. Springer-Verlag, Berlin, p 297-320

Sameoto DD (1976) Distribution of sound scattering layers caused by euphausiids and their relationship to chlorophyll a concentrations in the Gulf of St. Lawrence Estuary. J Fish Res Board Can 33:681-687

Saucier FJ, Chassé J (2000) Tidal circulation and buoyancy effects in the St. Lawrence Estuary, Canada. Atmos-Ocean 38:505-556

Saucier FJ, Roy F, Gilbert D, Pellerin P, Ritchie H (2003) Modeling the formation and circulation processes of water masses and sea ice in the Gulf of St. Lawrence, Canada. J Geophys Res C 108:3269-3289

Schoenherr JR (1991) Blue whales feeding on high concentrations of euphausiids around Monterey Submarine Canyon. Can J Zool 69:583-594

Simard Y, Lavoie D (1999) The rich krill aggregation of the Saguenay-St. Lawrence Marine Park: hydroacoustic and geostatistical biomass estimates, structure, variability, and significance for whales. Can J Fish Aquat Sci 56:1182-1197

Simard Y, de Ladurantaye R, Therriault JC (1986a) Aggregation of euphausiids along a coastal shelf in an upwelling environment. Mar Ecol Prog Ser 32:203-215

Simard Y, Lacroix G, Legendre L (1986b) Diel vertical migrations and nocturnal feeding of a dense coastal krill scattering layer (Thysanoessa raschi and Meganyctiphanes norvegica) in stratified surface waters. Mar Biol 91:93-105

Smith GC, Saucier FJ, Straub D (2006a) The formation and circulation of the cold intermediate layer in the Gulf of St. Lawrence. J Geophys Res C (in press)

Smith GC, Saucier FJ, Straub D (2006b) Response of a tidal estuary to external forcing in winter. J Phys Oceanogr (in press)

Tang CL (1980a) Mixing and circulation in the northwestern Gulf of St. Lawrence: a study of a buoyancy-driven current system. J Geophys Res C 85:2787-2796

Tang CL (1980b) Observation of wavelike motion of the Gaspé Current. J Phys Oceanogr 10:853-860

Tarling GA (2003) Sex-dependent diel vertical migration in northern krill Meganyctiphanes norvegica and its consequences for population dynamics. Mar Ecol Prog Ser 260: 173-188

Tarling GA, Buchholz F, Matthews JBL (1999) The effect of lunar eclipse on the vertical migration behaviour of Meganyctiphanes norvegica (Crustacea: Euphausiacea) in the Ligurian Sea. J Plankton Res 21:1475-1488

Therriault JC, Petrie B, Pepin P, Gagnon J and 8 others (1998) Proposal for a northwest Atlantic zonal monitoring program. Can Tech Rep Hydrogr Ocean Sci 194:1-57 
Thomasson MA, Johnson ML, Strömberg JO, Gaten E (2003) Swimming capacity and pleopod beat rate as a function of sex, size and moult stage in northern krill Meganyctiphanes norvegica. Mar Ecol Prog Ser 250:205-213

Visser AW, Thygesen UH (2003) Random motility of plankton: diffusive and aggregative contributions. J Plankton Res 25:1157-1168

Wroblewski JS (1982) Interaction of currents and vertical migration in maintaining Calanus marshallae in the Oregon upwelling zone-a simulation. Deep-Sea Res 29: 665-686

Yamazaki H, Squires KD (1996) Comparison of oceanic turbulence and copepod swimming. Mar Ecol Prog Ser 144: 299-301

Zakardjian BA, Runge JA, Plourde S, Gratton Y (1999) A bio-

Editorial responsibility: Otto Kinne (Editor-in-Chief),

Oldendorf/Luhe, Germany physical model of the interaction between vertical migration of crustacean zooplankton and circulation in the Lower St. Lawrence Estuary. Can J Fish Aquat Sci 56: $2420-2432$

Zalesak ST (1979) Fully multidimensional flux-corrected method transport algorithms for fluids. J Comp Physiol 31: 335-362

Zelikman EA, Lukashevich IP, Drobysheva SS (1978) Aggregative distribution of Thysanoessa inermis (Krøyer) and T. raschi (M. Sars) (Euphausiacea) in the Barents Sea. Oceanology 18:1077-1084

Zelikman EA, Lukashevich IP, Drobysheva SS (1979) Yearround diurnal vertical migrations of the euphausiids Thysanoessa inermis and T. raschi in the Barents Sea. Oceanology 19:132-138

Submitted: February 7, 2005; Accepted: October 6, 2005 Proofs received from author(s): May 2, 2006 